\title{
SIMULASI UJIAN ZIDS ONLINE BERBASIS MOODLE
}

\author{
Pepen Permana, Irma Permatawati, \& Ending Khoerudin \\ Departemen Pendidikan Bahasa Jerman \\ Universitas Pendidikan Indonesia \\ pepen@upi.edu; irma.permatawati@upi.edu; ending.khoerudin@upi.edu
}

How to cite (in APA Style): Permana, P., Permatawati, I., \& Khoerudin, E. (2018). Simulasi ujian ZIDS online berbasis Moodle. Barista: Jurnal Kajian Bahasa dan Pariwisata, 5(2), Desember 2018, 131-144.

\begin{abstract}
Abstrak: ZIDS adalah sertifikat kebahasajermanan yang wajib dimiliki oleh para mahasiswa bahasa Jerman di beberapa Universitas di Indonesia. Ujian untuk memeroleh sertifikat ZIDS (ZIDS-Prüfung) dilaksanakan tiap tahun di setiap universitas dan diikuti oleh mahasiswa semester IV. Menjelang pelaksanaan ujian ZIDS, selama ini Departemen Pendidikan Bahasa Jerman FPBS UPI selalu melaksanakan program persiapan ujian. Program persiapan ini dilakukan secara intesif setiap hari selama satu bulan menjelang pelaksanaan ujian ZIDS. Namun prestasi mahasiswa dalam ujian tersebut selama ini belum cukup menggembirakan, yang tercermin dari nilai rata-rata mereka yang masih berada di rentang 60-70\% dengan tingkat ketidaklulusan sekitar 10-20\%. Semenjak diberlakukannya kurikulum baru UPI tahun 2013, kini program persiapan ujian ZIDS tidak lagi dilakukan secara intensif, melainkan secara reguler dalam satu semester melalui mata kuliah baru, yakni ZIDS-Prüfungsvorbereitung. Hingga saat ini mata kuliah tersebut baru dilaksanakan dua kali, yakni pada semester genap tahun 2015 dan tahun 2016. Berhubung persiapan ujian ZIDS kini tidak lagi seintensif sebelumnya, maka diperlukan sebuah cara yang inovatif agar kualitas proses pembelajaran dan prestasi mahasiswa dalam ujian ZIDS meningkat. Cara tersebut adalah dengan mengembangkan program simulasi ujian ZIDS online berbasis aplikasi LMS Moodle, yang dapat membantu mahasiswa mempersiapkan diri dengan baik dan mandiri di luar perkuliahan dalam kelas. -
\end{abstract}

Kata kunci: LMS; Moodle; uji kompetensi bahasa; bahasa Jerman; ZIDS

\section{ZIDS ONLINE EXAM SIMULATION BASED ON MOODLE}

\begin{abstract}
ZIDS (Zertifikat für Indonesische DeutschStudierende), a compulsory language certificate for German students at some universities in Indonesia, has been voided from 2017. As a replacement, students are now advised to take the Goethe-Zertifikat B1. In addition to its benefits, this decision could bring challenges for both students and German departments in Indonesia. The higher level of difficulty and the different format of the exam would be new particular problems for the students. Therefore, the German departments are advised to make an extra effort to design an innovative attempt to prepare their students achieve satisfying performance at the exam. One of the efforts is to develop a Moodle-based exam simulation program. Since an own online exam simulation intended for ZIDS examination is already available at the UPI German department, it is now being attempted to reuse and further develop this exam simulation, so that it can be used not only for the Goethe-Zertifikat B1 but also is intended for other examinations in the future. This article is about what was achieved in the previous online exam simulation, and what should be done regarding the future online exam simulation for the Goethe-Zertifikat B1.
\end{abstract}

Keywords: ZIDS; Moodle; language competency test; simulation; German; B1 


\section{PENDAHULUAN}

Sejak tahun 2003 jurusan/prodi bahasa Jerman di beberapa perguruan tinggi di Indonesia mewajibkan para mahasiswanya untuk menempuh ujian kebahasajermanan tingkat nasional, yakni ujian ZIDS (Zertifikat für indonesische Deutschstudierende). Dengan dimilikinya sertifikat ZIDS ini, mahasiswa yang bersangkutan secara de jure memiliki kompetensi untuk berkomunikasi secara lisan dan tulisan dalam konteks situasi sehari-hari yang paling penting dalam bahasa Jerman.

Di Departemen Pendidikan Bahasa Jerman FPBS UPI ujian ini diselenggarakan setiap bulan Juni dan kepemilikan sertifikat ZIDS ini merupakan salah satu syarat untuk mengikuti ujian sidang skripsi. Sejak UPI memberlakukan kurikulum baru yang mengacu pada KKNI pada tahun 2013 lalu, kini posisi ujian ZIDS dalam kurikulum di Departemen Pendidikan Bahasa Jerman semakin dipertegas yang ditandai dengan hadirnya mata kuliah baru yang khusus mempersiapkan mahasiswa agar dapat menempuh ujian ZIDS ini dengan baik, yang bernama ZIDS-Prüfungsvorbereitung dan dengan bobot 2 sks.

Mata kuliah ini dilaksanakan untuk pertama kalinya pada semester genap tahun 2015 ini dengan jumlah mahasiswa yang mengontrak sejumlah 40 orang yang dibagi ke dalam dua kelas. Sebelum hadirnya mata kuliah ZIDSPrüfungsvorbereitung, Departemen Pendidikan Bahasa Jerman FPBS UPI biasanya melangsungkan program persiapan ujian tersendiri untuk para mahasiswa yang akan menempuh ujian ZIDS. Program ini bersifat ekstrakurikuler dan diselenggarakan secara intensif setiap hari selama satu bulan dengan durasi 100 menit per pertemuan.

Meski selama ini program persiapan ujian dilaksanakan secara intensif, namun hasil ujian ZIDS yang diraih oleh mahasiswa Departemen Pendidikan Bahasa Jerman FPBS UPI masih relatif belum menggembirakan. Hal ini tercermin dari perolehan nilai rata-rata ujian ZIDS tiap tahun yang selalu berada di kisaran $60-70 \%$ dari nilai maksimal yang diharapkan. Selain itu, tingkat ketidaklulusan para mahasiswa dalam ujian ZIDS ini berada pada rentang 10-20\%.

Berdasarkan hal tersebut di atas, muncul kekhawatiran jika di masa yang akan datang hasil yang diraih oleh mahasiswa dalam ujian ZIDS ini justru semakin tidak memuaskan. Dengan tidak bermaksud mengecilkan arti dan peran mata kuliah ZIDS-Prüfungsvorbereitung, kekhawatiran ini didasari oleh fakta bahwa saat ini persiapan ujian ZIDS tidak dilakukan secara intensif lagi, melainkan dilakukan secara reguler dalam perkuliahan. Secara kuantitas pertemuan, kini persiapan ujian ZIDS ini secara total hanya akan berjumlah 14-16 pertemuan dalam satu semester dan dilakukan seminggu satu kali. Jika dibandingkan dengan persiapan intensif yang dahulu dilakukan, jumlah pertemuan ini jelas mengalami penurunan kuantitas dari yang semula berjumlah total 20 pertemuan dengan intensitas pertemuan setiap hari selama satu bulan.

Agar kekhawatiran tersebut tidak terbukti, diperlukan sebuah cara yang inovatif dan interaktif yang dapat meningkatkan kualitas pelaksanaan persiapan ujian ZIDS, yang saat ini diwakili oleh mata kuliah ZIDSPrüfungsvorbereitung. Salah satu cara yang mungkin bisa menjadi solusi adalah dengan memaksimalkan peran internet dalam persiapan ujian ZIDS ini, yakni dengan menciptakan sebuah simulasi ujian ZIDS (ZIDS-Prüfungssvorbereitung) secara online. Dengan tersedianya program tersebut, mahasiswa diharapkan dapat mempersiapkan dirinya dengan baik secara mandiri. Karena sifatnya online, mahasiswa dapat mengakses program tersebut di mana saja dan kapan saja tanpa terbatas ruang dan waktu. Dengan demikian, minimnya jumlah pertemuan di dalam kelas, dapat diatasi dengan adanya program simulasi online berbasis Moodle ini.

Kini sudah banyak tersedia berbagai kemungkinan untuk mengoptimalkan peran internet dalam pembelajaran, salah satunya adalah pemanfaatan Learning Management System (LMS). LMS adalah sebuah aplikasi online yang memiliki kemampuan untuk mengadministrasi, melacak, dan melaporkan serangkaian 
program dan aktivitas perkuliahan (Ellis: 2009). LMS ini memungkinkan penggunanya untuk dapat berinteraksi dengan lingkungan dan konten pembelajaran secara aktif dan interaktif.

Salah satu platform LMS yang populer adalah Moodle (Modular ObjectOriented Dynamic Learning). Moodle adalah produk yang bersifat open source yang dirancang oleh komunitas online yang luas, yang meliputi para programmer, ahli pendidikan, penerjemah, dan sebagainya. Moodle ini juga senantiasa mengalami perkembangan dari waktu ke waktu. Moodle menawarkan berbagai jenis modul pembelajaran online yang mudah disesuaikan dengan jenis dan tujuan pembelajaran. Sahin-Kizil (2014:184) menyatakan, bahwa pembelajar penggunaan Moodle dalam pembelajaran mendapatkan respon yang positif dari para pembelajar, terutama bagi mereka yang terlibat dalam pembelajaran bahasa.

Dengan fiturnya yang beragam Moodle juga memudahkan para pengajar untuk menciptakan seperangkat alat evaluasi yang aman dan mudah diatur sesuai kebutuhan. Terdapat lebih dari 20 aktivitas pembelajaran online yang dapat dikonfigurasi sedemikian rupa oleh para pengajar, seperti forum diskusi, glossar, wiki, kuis dan lain sebagainya. Kemudahan atau kemampuan Moodle dalam menyediakan aktivitas-aktivitas yang mudah dikonfigurasi ini meruipakan suatu hal yang menarik, karena dengan demikian pengajar memiliki keleluasaan dalam mengatur untuk jalur pembelajaran yang harus ditempuh oleh pembelajar demi mencapai tujuan pembelajaran. Selain itu, hasil aktivitas pembelajaran yang telah ditempuh dapat juga digunakan untuk menjadi dasar atau landasan terhadap aktivitas pembelajaran selanjutnya.

Dari

laman

https://docs.moodle.org/29/en/Activities kita bisa mengetahui berbagai modul yang disediakan oleh Moodle, di antaranya:

1. Assignment, yakni modul yang memungkinkan pengajar memberikan nilai atau komentar terhadap tugas-tugas yang diunggah oleh pembelajar. Tugas tersebut bisa dikerjakan secara online ataupun offline.

2. Chat, yakni fasilitas yang memungkinkan para penggunanya untuk melakukan percakapan langsung secara real-time.

3. Choice, yakni fasilitas semacam poling. Pengajar memberikan pertanyaan pada para pembelajar. Pilihan jawaban untuk pertanyaan ini bisa mendapat respon lebih dari satu.

4. Database, yakni modul yang memfasilitasi para pembelajar untuk membuat, mengelola, dan mencari sekumpulan entri data.

5. External Tool, yakni perangkat yang dapat membantu siswa berinteraksi dengan sumber belajar LTI (Learning Tool Interoperability) yang sesuai dan memberikan aksis bagi mahasiswa untuk melakukan kegiatan pembelajaran di website lain.

6. Feedback, yakni alat untuk menciptakan dan melakukan survry untuk mengumpulkan umpan balik.

7. Forum, yakni fasilitas yang memungkinkan para pengguna untuk berdiskusi secara asynchronous membahas topiktopik pembelajaran.

8. Glossary, yakni modul semacam kamus online, di mana pembelajar bisa membuat dan memelihara daftar-daftar kata atau definisi.

9. Lesson, yakni modul pembelajaran yang berisi halaman HTML bernavigasi. Dengan alat ini, konten pembelajaran dapat disampaikan secara fleksibel.

10. Quiz, yang memungkinkan pengajar untuk merancang dan mengatur tes atau kuis. Setiap jawaban pembelajar dalam kuis ini dapat secara otomatis diketahui benar/salahnya dan diberikan umpan balik langsung.

11. SCORM, yakni modul yang memungkinkan paket SCORM untuk dimasukkan dalam konten pembelajaran. SCORM (Shareble Content Object Reference Model) adalah standar pendistribusian 
paket pembelajaran elektronik yang dapat digunakan untuk menampung berbagai macam format materi pembelajaran, baik dalam bentuk teks, animasi, audio dan video

12. Survey, yakni modul untuk mengumpulkan data dari pembelajar tentang respon dan evaluasi mereka terhadap pembelajaran.

13. Wiki, yakni fasilitas yang memunkinkan pengguna untuk membuat seprangkat halaman web yang dapat ditambahkan atau disunting oleh siapapun.

14. Workshop, yakni aktivitas yang memungkinkan terjadi penilaian sejawat oleh para pembelajar.

Selain modul-modul dasar yang ditawarkan Moodle, terdapat juga ratusan modul dan plugin dari pihak ketiga yang dapat di-install sesuai kebutuhan pembelajaran. Dari segi teknis, untuk dapat menjalankan aplikasi LMS Moodle ini dengan baik setidaknya diperlukan Apache Web Server, PHP dan Database MySQL atau PostgreSQL. Moodle juga mendukung berbagai bahasa sebagai bahasa pengantarnya, termasuk bahasa Indonesia. Dari website resminya (http://docs.moodle.org/de/Philosophie) dijelaskan, bahwa perancangan dan pengembangan Moodle didasari oleh sebuah konsep filosofi pembelajaran yang secara sederhana bisa disebut dengan social constructionist pedagogy (SCP). Filosofi SCP ini dilatarbelakangi pula oleh empat konsep utama yang saling bersinergi, yakni (1) Konstruktivisme, (2) Konstruksionisme, (3) Konstruktivisme sosial, dan (4) paham connected and separate (terhubung dan terpisah).

Konstruktivisme beranggapan bahwa orang mengembangkan pengetahuan mereka secara aktif melalui interaksi dengan lingkungannya. Apa yang kita baca, lihat, dengar, rasa, dan sentuh yang berhubungan dengan panca indera kita - dihubungkan dengan pengetahuan awal kita lalu dimasukkan dalam akal pikiran kita. Dengan demikian, munculah pengetahuan baru yang kita dapatkan. Pengetahuan akan kuat tersimpan, jika dapat dimanfaatkan dengan baik dalam situasi yang lain. Manusia merupakan penerima pengetahuan yang aktif.

Konstruksionisme menegaskan bahwa pembelajaran akan sangat efektif jika konten pembelajaran diproses dan aktif diterapkan bagi kepentingan orang lain. Hal ini dapat dihasilkan melalui suatu kegiatan pembelajaran yang melibatkan para pembelajar untuk berperan aktif bukan hanya pasif menerima saja. Dengan demikian dapat dikatakan, bahwa pembelajaran itu efektif, jika dirancang untuk menghjasilkan sesuatu yang berguna bagi orang lain.

Konstruktivisme sosial merupakan perluasan makna konstruktivisme dalam konteks lingkungan sosial. Istilah ini (juga konsep connected and separate) merupakan implikasi terapan dari proyek penelitian doktoral milik para pengembang Moodle, Dougiamas \& Taylor, (Nozawa, 2011:920). Konstruktivisme sosial ini berpendapat, bahwa jika ide pikiran itu disajikan dalam sebuah kelompok yang memiliki kultur berbagi pengetahuan dan memiliki konteks kebermaknaan yang sama, maka individu di dalamnya akan belajar terus menerus pada berbagai tingkatan.

Paham connected and separate merupakan sebuah paham baru yang mengkaji lebih dalam mengenai motif dan interaksi individu dalam berdiskusi. Menurut paham ini terdapat tiga jenis perilaku individu dalam diskusi, yakni perilaku "terpisah" (separate), "terhubung" (connected), dan "terbangun" (constructed). Perilaku separate adalah ketika seseorang mencoba untuk tetap objektif dan faktual, dan cenderung mempertahankan pendapat dengan menggunakan logika untuk mencari celah kelemahan dari pendapat lawannya. Perilaku connected lebih menggunakan pendekatan empatik dan menerima subjektivitas, mereka mencoba untuk mendengar dan bertanya sebagai upaya untuk memahami sudut pandang orang lain. Perilaku constructed adalah mereka yang peka terhadap kedua perilaku di atas, dan mampu menentukan perilkau mana yang tepat untuk situasi yang sedang dialami. 
Dougiamas dalam Nozawa (2011:290) menyatakan bahwa paham konstruktivisme menekankan bahwa pembelajar harus dilibatkan dalam membangun pengetahuannya agar dapat dilihat oleh pembelajar lainnya. Lebih lanjut juga dijelaskan bahwa makna keempat paham yang memengaruhi paham SCP adalah sebagai berikut:

1. Konstruktivisme: pengetahuan diciptakan melalui interaksi dengan lingkungan.

2. Konstruksionisme: efektivitas belajar efektivitas dapat diamati ketika menciptakan sesuatu yang berguna untuk orang lain.

3. Konstruktivisme sosial: pergerakan menuju seluruh masyarakat membentuk budaya dan kebermaknaan.

4. Perilaku terhubung: tindakan cermat menstimulasi belajar.

Interaksi pembelajar dengan lingkungannya merupakan hal yang paling utama yang diusung pembelajaran online berbasis Moodle. Dengan demikian diharapkan agar mahasiswa dapat belajar mandiri demi membangun pengetahuannya sendiri, berbagi dan mendiskusikan pengetahuan tersebut dengan pembelajar lain, dan agar bisa menghargai perbedaan pendapat. Seperti yang Alvarez dan Gonzales (2007:5) tekankan, bahwa Moodle sangat berfokus pada peran kontribusi para pengguna yang terlibat dalam semua proses pembelajaran. Dengan demikian, Moodle merupakan kombinasi antara perspektif yang dinamis dan stimulasi kreativitas.

Moodle tidak berarti memaksa untuk menerapkan gaya perilaku tertentu dalam pembelajaran. Paham-paham yang diuraikan di atas dipercaya menurut para pengembangnya merupakan hal yang paling sesuai dalam mendukung pembelajaran dengan aplikasi LMS Moodle. Dengan demikian, konsep pedagodi yang mendasari pengembangan Moodle ini bisa dijadikan pertimbangan dalam menentukan pengalaman apa yang pantas didapat oleh pembelajar dalam pembelajaran online, bukan hanya sekedar menampilkan informasi atau materi pembelajaran menurut pengajar perlu diketahui oleh pembelajar.
Tugas pengajar dalam Moodle dapat beralih fungsi. Mereka tidak lagi berperan sebagai pemberi pengetahuan semata, tapi juga berperan sebagai role model yang memfasilitasi para pembelajar untuk mengenali kebutuhan belajarnya dan mengantarkan mereka meraih tujuan pembelajaran. Lebih lanjut dalam laman https://docs.moodle.org/29/de/Moodle_in _der_Bildung diungkapkan pula bahwa pada hakikatnya pembelajaran melalui Moodle ini didasari oleh lima hal pokok, yakni:

1. Kita semua senantiasa berperan sebagai pembelajar sekaligus pengajar.

2. Kita belajar dengan baik, terutama jika dapat menjelaskan sesuatu kepada orang lain mengembangkan sesuatu yang bermanfaat untuk orang lain.

3. Kita belajar banyak jika kita diperhatikan oleh orang lain.

4. Kita mengalami perubahan diri, jika kita kita memahami orang lain.

5. Kita belajar dengan baik, jika lingkungan kita fleksibel dan sesuai dengan kebutuhan dan tuntutan kita.

Namun demikan, aplikasi Moodle tidak dapat menciptakan situasi belajar demikian dengan sendirinya. Tapi Moodle dapat mendukung terciptanya situasi belajar yang diharapkan secara efektif. Moodle membantu menyadari bahwa antara pengajar dan pembelajar memiliki posisi yang setara dalam pembelajaran online, di mana peran seorang pengajar bukan lagi sebagai 'sumber pengetahuan' belaka tapi juga sebagai panutan dan motivator yang memfasilitasi para pembelajar beraktivitas untuk memenuhi kebutuhan belajarnya demi tercapainya tujuan pembelajaran yang diharapkan. Sebagaimana Nozawa (2011:309) menekankan bahwa Moodle itu sendiri tidak mengedepankan pembelajaran yang berdiri sendiri, dengan demikian efektivitas pembelajaran mutlak berada pada cara partisipasi guru secara aktif dan interaktif.

\section{METODE}

Penelitian ini berfokus pada pengembangan simulasi ujian ZIDS online berbasis Moodle. Penelitian ini menggunakan pendekatan Research \& Development (R \& D). Dengan langkah define, design, develop und disseminate (Borg \& Gall,1979) produk 
dikembangkan berdasar pada temuantemuan penelitian. Temuan-temuan yang diperoleh dalam penelitian awal dijadikan dasar dalam pengembangan produk yang kemudian diujikan dalam suatu situasi dan dilakukan revisi terhadap ujicoba tersebut. Produk yang akan di hasilkan dalam penelitian ini berbentuk tak benda, yakni seperangkat modul aktivitas ujian ZIDS online berbasis Moodle.

Subjek penelitian ini adalah para mahasiswa Departemen Pendidikan Bahasa Jerman semester IV yang tengah mengontrak mata kuliah ZIDS-Vorbereitung yang berjumlah 54 orang. Setelah pengembangan produk simualsi ujian ZIDS online dilakukan pula beberapa ujicoba untuk mengetahui efektivitas program tersebut dalam meningkatkan kualitas lulusan ujian ZIDS.

Secara keseluruhan kegiatan penelitian mengenai pengembangan program simulasi ujian ZIDS online ini terbagi ke dalam lima tahap utama, yakni tahap pengumpulan informasi, perencanaan produk, pengembangan draft produk, uji coba awal, dan revisi produk utama. Dari lima tahapan tersebut, hingga saat ini penelitian sudah berada pada tahap keempat, yakni tahap ujicoba awal.

Pada tahap awal, kegiatan penelitian mencakup analisis kebutuhan, studi literature, dan obervasi lapangan. Pada tahap ini dilakukan pengumpulan referensi dan ide-ide terkait pengembangan bentuk produk simulasi ZIDS online ini. Dari kegiatan tahap awal ini terkumpul beberapa sumber bahan materi yang akan dijadikan konten dalam produk ZIDSPrüfungssimulation ini. Materi-materi yang dijadikan konten simulasi ZIDS ini bersumber buku-buku latihan ujian kebahasajermanan, yakni Testheft Studio D B1, ZD 15 Übungsprüfungen, Zertifikat B1 Neu, dan Testheft B1, dan dari beberapa website, diantaranya http://samstagsblattmuenchen.de, http://onlinestreet.de, http://www.geolino.de, http://www.studentenjobs24.de, http://www.wochenanzeiger-

muenchen.de, dan http://www.hallomuenchen.de.

Setelah sumber-sumber referensi terkumpul, kegiatan penelitian berlanjut ke tahap perencanaan produk. Di tahap ini dilakukan pengumpulan materi untuk dijadikan bahan-bahan pembuatan soal untuk simulasi ujian ZIDS. Setelah terkumpul bahan-bahan yang diperlukan, maka selanjutnya dilakukan pembuatan bank soal. Soal-soal yang dijadikan konten untuk program simulasi ini terdiri dari empat bagian, yakni soal untuk LV, SB, HV, dan SA. Kegiatan pada tahap ini sudah menghasilkan tiga paket soal untuk masingmasing mata uji. Sebagian dari soal-soal tersebut diambil dan dimodifikasi dari buku-buku rujukan, dan sebagian lagi merupakan soal buatan sendiri.

Tabel 1. Ringkasan Jumlah Soal Program Simulasi Ujian ZIDS Online

\begin{tabular}{lclcc}
\hline Mata uji & Bagian & Jenis soal & $\begin{array}{c}\text { Jumlah } \\
\text { soal }\end{array}$ & $\begin{array}{c}\text { Jumlah } \\
\text { paket }\end{array}$ \\
\hline LV & Teil 1 & Menjodohkan & 5 & 3 \\
\cline { 2 - 5 } & Teil 2 & Pilihan ganda & 5 & 3 \\
\cline { 2 - 5 } & Teil 3 & Menjodohkan & 10 & 3 \\
\hline SB & Teil 1 & Pilihan ganda & 5 & 3 \\
& Teil 2 & Menjodohkan & 10 & 3 \\
\hline \multirow{2}{*}{ HV } & Teil 1 & Pilihan ganda & 5 & 3 \\
\hline SA & Teil 2 & Benar-Salah & 10 & 3 \\
\hline
\end{tabular}

Tahap penelitian selanjutnya adalah tahap pengembangan draft produk. Di tahap ini

dilakukan penyusunan konsep produk ujian simulasi online yang akan dikembangkan, yang meliputi pembuatan mata kuliah baru di aplikasi Moodle, pemetaan dan navigasi alur program simulasi ujian dan penataan layout 
tampilannya. Selain itu, soal-soal yang sudah terkumpul di bank soal sebelumnya juga diunggah ke bank soal yang tersedia dalam aplikasi Moodle, sehingga soal-soal yang sudah ada tersebut dikonversi menjadi soal-soal yang compatible dengan sistem soal yang tersedia di Moodle.

Setelah tahap pengembangan draft produk, kemudian dilakukan tahap ujicoba awal (uji coba terbatas) yang mellibatkan mahasiswa semester IV bahasa Jerman UPI. Di tahap ini juga dilakukan penyebaran angket kepada mahasiswa untuk mengetahui kesan dan penilaian mereka terhadap produk simulasi ujian ZIDS online ini. Hasil dari ujicoba terbatas ini kemudian menjadi dasar dalam tahap selanjutnya, yakni tahap revisi. Pada tahap revisi ini, dilakukan perbaikan produk sesuai dengan masukan-masukan yang diterima pada tahap sebelumnya. Hasil revisi produk ini kemudian dikembangkan lagi menjadi sebuah produk final.

\section{HASIL DAN PEMBAHASAN}

Penelitian ini bercita-cita menghasilkan sebuah produk simulasi ujian ZIDS online berbasis LMS Moodle. Saat ini penelitian ini masih berjalan dan telah menginjak bulan ke lima dari durasi tiga tahun yang direncanakan. Untuk tahun pertama ini target yang hendak dicapai oleh penelitian ini adalah terciptanya sebuah draft produk awal simulasi ujian ZIDS online yang baru bisa diujicobakan secara terbatas untuk mahasiswa UPI saja. Untuk tahun berikutnya, produk awal tersebut akan lebih dikembangkan agar bisa diakses pula secara nasional.

Keberadaan ujian ZIDS ini terlahir berkat kerjasama para perwakilan jurusan/prodi bahasa Jerman dari beberapa Universitas dengan pihak Goethe Institut Jakarta. Kerjasama ini dilatarbelakangi oleh dibutuhkannya sebuah alat untuk mengevaluasi dan menentukan standar kemampuan berbahasa Jerman bagi para mahasiswa. Berkat kerjasama ini pula Goethe-Institut bersedia menyusun ujian ini untuk diterapkan di universitas-universitas di Indonesia. Selain menentukan perangkat ujian mana yang akan digunakan setiap tahunnya, Goethe-Institut juga melatih dan menetapkan para dosen yang berwenang melaksanakan ujian ZIDS ini.

Berdasarkan perjanjian kerjasama antara Direktur Pembinaan Tenaga Kependidikan dan Ketenagaan Perguruan Tinggi Direktorat Jendral Pendidikan Tinggi dan Goethe-Institut Jakarta yang ditandatangani pada tanggal 5 September 2002, ujian ZIDS ini merupakan komponen wajib dalam kurikulum setiap jurusan/prodi bahasa Jerman dan bersifat wajib tempuh dan wajib lulus bagi para mahasiswanya.

Penyusunan perangkat ujian ZIDS ini dilakukan secara nasional, dan penyelenggaraan ujiannya dilaksanakan secara lokal di beberapa Universitas di Indonesia untuk para mahasiswa semester IV. Saat ini tercatat ada sepuluh universitas di Indonesia yang sudah menerapkan ujian ZIDS ini, yakni Universitas Pattimura Ambon, Universitas Pendidikan Indonesia, Universitas Negeri Jakarta, Universitas Naegeri Malang, Universitas Negeri Manado, Universitas Negeri Medan, Universitas Negeri Surabaya, Universitas Negeri Makassar, Yogyakarta, dan Universitas Nommensen Pematang Siantar. Soal-soal yang diberikan pada ujian ZIDS ini dirancang untuk dapat setara dengan level B1 pada standar GER (Gemeinsamer Europäischer Referenzrahmen), kerangka acuan penilaian dan pembelajaran bahasa yang berlaku di Eropa. Secara umum level B1 ini, yang disadur dari laman http://www.goethe.de, adalah tingkatan berbahasa yang menunjukan kompetensi seseorang dalam menggunakan bahasa secara mandiri, yang ditunjukkan dengan kemampuan untuk dapat:

1. memahami pokok utama dari bahasa baku yang digunakan dan yang berkenaan dengan tema sehari-hari, seperti lingkungan kerja, sekolah, rekreasi dan sebagainya;

2. menangani situasi yang umum terjadi jika berada di negara yang menggunakan bahasa yang bersangkutan;

3. mengungkapkan wacana sederhana yang berterima dengan tema yang 
familiar atau tema yang bersifat personal;

4. menceritakan pengalaman, peristiwa, impian, harapan dan citacita, dan secara ringkas dapat memberi alasan dan penjelasan dalam berpendapat atau merencanakan sesuatu.

Deskripsi kemampuan level B1 skala umum di atas kemudian dapat dijabarkan secara rinci berdasar aspek penilaian mandiri sebagai berikut (tabel 1):

Tabel 2. Matriks Tingkat B1 dalam Aspek Penilaian Mandiri

\begin{tabular}{|c|c|c|}
\hline \multicolumn{2}{|c|}{ Aspek Bahasa } & Uraian Kompetensi \\
\hline \multirow{2}{*}{ 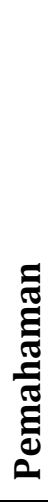 } & Menyimak & $\begin{array}{l}\text { - Dapat memahami ide pokok dari bahasa baku yang digunakan } \\
\text { dan yang berkenaan dengan hal-hal sehari-hari seperti } \\
\text { pekerjaan, sekolah, waktu luang dan sebagainya } \\
\text { - Jika diucapkan secara relativ lambat dan jelas, dapat menangkap } \\
\text { informasi utama dari berbagai acara radio atau TV tentang } \\
\text { peristiwa aktual dan tentang topik yang berkenaan dengan } \\
\text { bidang pekerjaan atau minat sendiri. }\end{array}$ \\
\hline & Membaca & $\begin{array}{l}\text { - Dapat memahami teks yang secara umum berisi tentang bahasa } \\
\text { sehari-hari atau yang berkenaan dengan pekerjaan. } \\
\text { - Dapat memahami surat pribadi yang menceritakan peristiwa, } \\
\text { perasaan dan harapan. }\end{array}$ \\
\hline \multirow{2}{*}{ 茪 } & $\begin{array}{l}\text { Terlibat dalam } \\
\text { berbagai dialog }\end{array}$ & $\begin{array}{l}\text { - Dapat menangani sebagian besar situasi yang mungkin terjadi } \\
\text { jika berada di negara yang menggunakan bahasa tersebut. } \\
\text { - Dapat berpartisipasi tanpa persiapan dalam percakapan } \\
\text { mengenai tema yang sesuai minat, atau mengenai tema sehari- } \\
\text { hari, seperti keluarga, hobi, pekerjaan, wisata dan peristiwa } \\
\text { aktual. }\end{array}$ \\
\hline & $\begin{array}{c}\text { Percakapan } \\
\text { mutual }\end{array}$ & $\begin{array}{l}\text { - Dapat mendeskripsikan secara lisan tentang pengalaman dan } \\
\text { peristiwa atau impian, harapan dan cita-cita dalam kalimat } \\
\text { sederhana yang koheren. } \\
\text { - Dapat secara ringkas menjelaskan dan berargumen tentang } \\
\text { pendapat dan rencana pribadi. } \\
\text { - Dapat menceritakan sebuah kisah atau alur sebuah film atau } \\
\text { buku, dan mendeskripsikan reaksi sendiri. }\end{array}$ \\
\hline & Menulis & $\begin{array}{l}\text { - Dapat menulis teks dengan jelas dan detil tentang berbagai tema } \\
\text { yang sesuai minat. } \\
\text { - Dapat menyampaikan informasi dalam sebuah karangan atau } \\
\text { laporan, atau menyampaikan argumen pro/kontra terhadap } \\
\text { sudut pandang tertentu. } \\
\text { - Dapat menulis surat yang mengungkapkan penilaian pribadi } \\
\text { tentang berbagai peristiwa atau pengalaman. }\end{array}$ \\
\hline
\end{tabular}

Sementara jika ditinjau dari aspek kualitatif penggunaan bahasa secara lisan kompetensi tingkat B1, yang meliputi aspek Spektrum (cakupan), Korrekheit (ketepatan), Flüssigkeit (kefasihan), Interaktion (interaksi), dan Kohärenz (koherensi), dapat diuraikan dalam tabel 2 di bawah ini: 
Tabel 3. Aspek Kualitatif Penggunaan Bahasa Lisan Tingkat B1

\begin{tabular}{|l|l|}
\hline \multicolumn{1}{|c|}{ Aspek } & \multicolumn{1}{|c|}{ Deskripsi } \\
\hline Spektrum & $\begin{array}{l}\text { Memiliki kemahiran kebahasaan yang mencukupi dalam melibatkan diri } \\
\text { dalam percakapan; memiliki Kosakata yang cukup untuk dapat } \\
\text { mengungkapkan topic seperti keluarga, hobi dan minat, pekerjaaan, } \\
\text { perjalanan, dan peristiwa aktual. Menggunakan parafrase jika terjadi } \\
\text { keraguan. }\end{array}$ \\
\hline Korrektheit & $\begin{array}{l}\text { Menggunakan repertoar yang relatif tepat untuk struktur dan bentuk ujaran } \\
\text { yang berkaitan dengan situasi yang dapat diprediksi. }\end{array}$ \\
\hline Flüssigkeit & $\begin{array}{l}\text { Dapat mengungkapkan secara lisan dengan lancar dan dapat dipahami ketika } \\
\text { berbicara bebas dan panjang, meski terdapat jeda untuk memilih kata dan } \\
\text { kalimat yang benar secara gramatis. }\end{array}$ \\
\hline Interaktion & $\begin{array}{l}\text { Dapat melangsungkan dan mengakhiri percakapan sederhana tentang topik } \\
\text { yang familiar atau yang sesuai minat. Dapat mengulang sebagian yang orang } \\
\text { lain katakan, demin menjaga pemahaman satu sama lain. }\end{array}$ \\
\hline Kohärenz & $\begin{array}{l}\text { Dapat mengaitkan serangkaian unsur-unsur informasi yang singkat dan } \\
\text { sederhana menjadi ungkapan yang linear dan koheren. }\end{array}$ \\
\hline
\end{tabular}

Ujian ZIDS sendiri mengukur kemampuan mahasiswa dalam keempat aspek berbahasa ditambah satu aspek yang mengukur penguasaan tatabahasa. Dengan demikian ujian ZIDS dari lima bagian, yakni Leseverstehen (LV), Sprachbausteine (SB), Hörverstehen (HV), Schriftlicher Ausdruck (SA) dan Mündlicher Ausdruck (MA). Mata uji LV menguji pemahaman membaca, SB menguji penguasaan tata bahasa, HV menguji kemampuan menyimak, SA menguji kemampuan menulis dan MA menguji kemampuan berbicara. Mata uji yang dikembangkan dalam produk simulasi ujian ZIDS dalam penelitian ini adalah mata uji yang sifatnya tertulis, karena mata uji MA - setidaknya untuk saat ini - tidak mungkin dilakukan secara online.

Secara keseluruhan ujian ZIDS terdiri dari berbagai macam soal yang dissuaikan dengan kompetensi yang hendak dicapai. Tabel 4 di bawah ini merupakan ringkasan format ujian ZIDS yang selama ini diselenggarakan, disadur dari naskah pedoman penyusunan soal ujian ZIDS (Handreichung zur Erstellung von Prüfungsaufgaben ZIDS).

\begin{tabular}{|c|l|l|l|l|}
\hline $\begin{array}{c}\text { Mata } \\
\text { Uji }\end{array}$ & \multicolumn{1}{|c|}{$\begin{array}{c}\text { Standar } \\
\text { Kompetensi }\end{array}$} & \multicolumn{1}{|c|}{ Tujuan } & Jenis Wacana & \multicolumn{1}{|c|}{ Bentuk soal } \\
\hline $\mathbf{L V}$ & $\begin{array}{l}\text { Membaca untuk } \\
\text { orientasi }\end{array}$ & $\begin{array}{l}\text { Bag. 1: Menguji } \\
\text { pemahaman global (ide } \\
\text { pokok) }\end{array}$ & $\begin{array}{l}\text { Teks pendek } \\
\text { dari koran, } \\
\text { majalah, atau } \\
\text { internet }\end{array}$ & $\begin{array}{l}\text { 5 soal } \\
\text { Menjodohkan 10 } \\
\text { judul yang tepat } \\
\text { untuk 5 teks }\end{array}$ \\
\cline { 3 - 5 } & $\begin{array}{l}\text { Bag. 2: Menguji } \\
\text { pemahaman detil (ide } \\
\text { pokok dan informasi } \\
\text { tertentu) }\end{array}$ & $\begin{array}{l}\text { Artikel koran } \\
\text { atau majalah }\end{array}$ & $\begin{array}{l}\text { 5 soal Pilihan } \\
\text { ganda dengan 3 } \\
\text { opsi }\end{array}$ \\
\cline { 2 - 6 } & $\begin{array}{l}\text { Memahami } \\
\text { informasi dan } \\
\text { argumen }\end{array}$ & $\begin{array}{l}\text { Bag. 3: Menguji } \\
\text { pemahaman selektif } \\
\text { (informasi tertentu) }\end{array}$ & $\begin{array}{l}\text { Iklan pendek } \\
\text { dari surat kabar }\end{array}$ & $\begin{array}{l}\text { 10 soal } \\
\text { menjodohkan 10 } \\
\text { situasi dengan 12 } \\
\text { iklan }\end{array}$ \\
\hline SB & $\begin{array}{l}\text { Membaca \& } \\
\text { memahami isi } \\
\text { korespondensi }\end{array}$ & $\begin{array}{l}\text { Bag. 1: Menguji } \\
\text { penguasaan grammatik }\end{array}$ & Surat resmi & $\begin{array}{l}5 \text { soal teks } \\
\text { rumpang dengan } \\
\text { pilihan ganda 4 } \\
\text { item }\end{array}$ \\
\hline
\end{tabular}




\begin{tabular}{|c|c|c|c|c|}
\hline & & $\begin{array}{l}\text { Bag. 2: Menguji } \\
\text { penguasaan leksik }\end{array}$ & Surat informal & $\begin{array}{l}10 \text { soal teks } \\
\text { rumpang dengan } \\
15 \text { opsi jawaban } \\
\text { ( } 5 \text { distraktor) }\end{array}$ \\
\hline \multirow[t]{2}{*}{ HV } & $\begin{array}{l}\text { Memahami } \\
\text { informasi yang } \\
\text { diperdengarkan }\end{array}$ & $\begin{array}{l}\text { Bag. 1: Menguji } \\
\text { pemahaman global dan } \\
\text { detil. }\end{array}$ & $\begin{array}{l}\text { Percakapan } \\
\text { antara } 2-3 \\
\text { orang }\end{array}$ & $\begin{array}{l}5 \text { soal pilhan } \\
\text { ganda dengan } 3 \\
\text { opsi }\end{array}$ \\
\hline & $\begin{array}{l}\text { Memahami } \\
\text { percakapan dari } \\
\text { dua orang native } \\
\text { speaker }\end{array}$ & $\begin{array}{l}\text { Bag. 2: Menguji } \\
\text { pemahaman detil. }\end{array}$ & $\begin{array}{l}\text { Percakapan } \\
\text { yang lebih } \\
\text { panjang antara } \\
2-3 \text { orang. }\end{array}$ & $\begin{array}{l}10 \text { soal benar- } \\
\text { salah }\end{array}$ \\
\hline SA & Interaksi tertulis & $\begin{array}{l}\text { Menulis surat informal } \\
\text { sesuai situasi yang } \\
\text { diminta }\end{array}$ & - & Uraian \\
\hline \multirow[t]{2}{*}{ MA } & Monolog & $\begin{array}{l}\text { Bag. 1: menceritakan } \\
\text { pengalaman }\end{array}$ & & $\begin{array}{lr}\text { Lembar poin } \\
\text { yang harus } \\
\text { diceritakan }\end{array}$ \\
\hline & Diskusi & $\begin{array}{l}\text { Bag. 2: } \\
\text { mengungkapkan } \\
\text { pendapat; } \\
\text { menyelesaikan } \\
\text { masalah, } \\
\text { mengungkapkan } \\
\text { persetujuan. }\end{array}$ & & Lembar roleplay \\
\hline
\end{tabular}

Program simulasi ujian ZIDS online ini terinstal di web e-learning milik Departemen Pendidikan Bahasa Jerman UPI dan dapat langsung diakses dengan mengetik URL http://jerman.upi.edu/zids. Karena berbasis Moodle, maka hanya pengguna yang telah terdaftar saja yang dapat masuk ke dalam sistem pembelajaran tersebut. Segera setelah pengguna masuk ke dalam sistem, mereka dapat mengakses program simulasi ini yang terdapat pada mata kuliah ZIDS-Vorbereitung. Setelah melakukan konfirmasi, maka pengguna dapat mengerjakan simulasi ujian ZIDS sesuai waktu yang disediakan, yakni 150 menit. Jumlah kesempatan mahasiswa untuk melakukan simulasi dalam program ini tidak dibatasi, artinya mereka dapat mencoba simulasi ini berkali-kali sesuai keinginan mereka. 


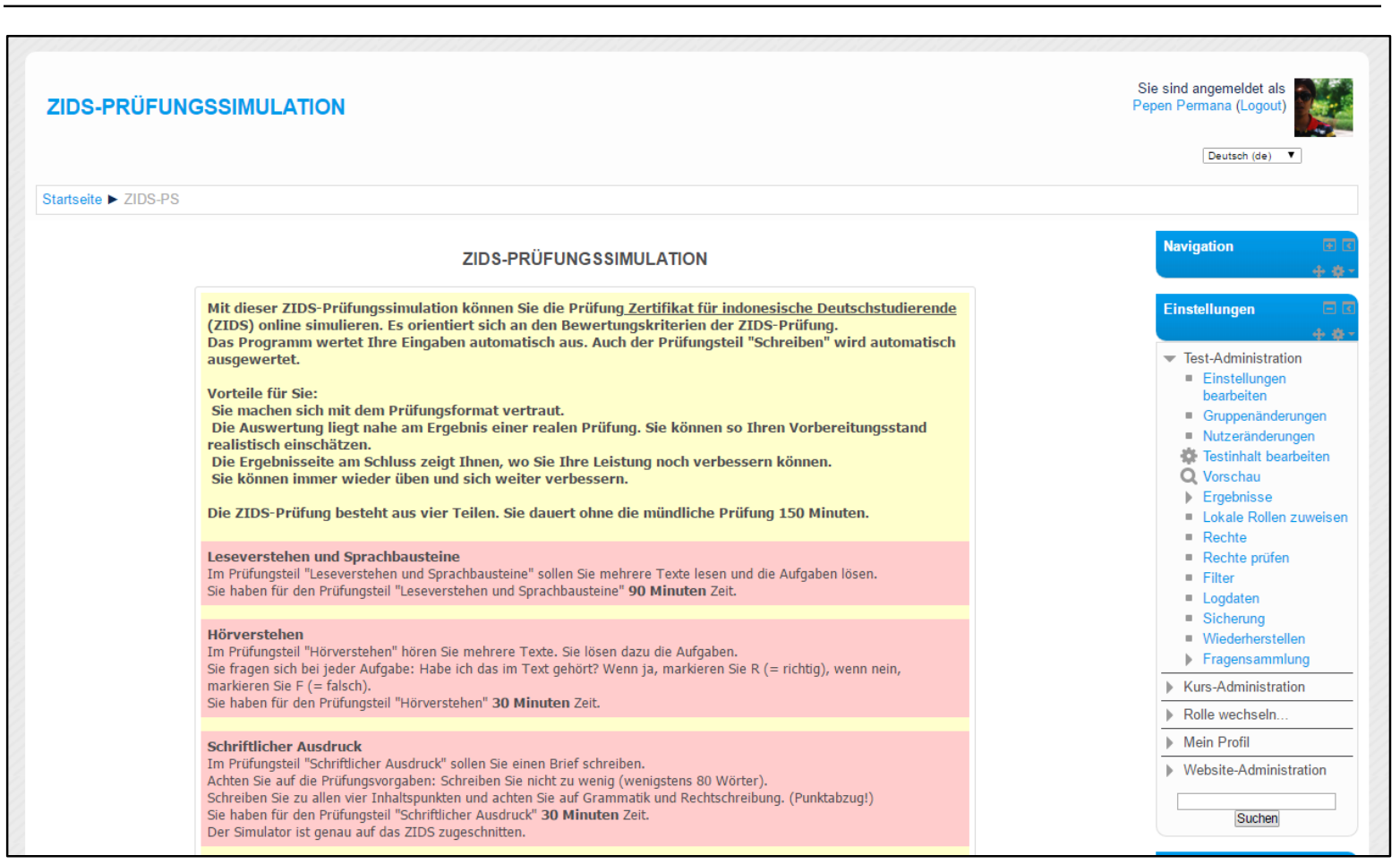

Gambar 1. Halaman Awal Program Simulasi Ujian ZIDS Online

Secara keseluruhan program simulasi ujian ZIDS online ini terdiri dari 10 halaman, yakni satu halaman awal, satu halaman akhir / halaman hasil, dan delapan halaman ujian. Halaman awal berisi petunjuk tentang simulasi ujian. Dengan mengeklik tombol "Test jetzt durchführen" dan melakukan konfirmasi, mahasiswa langsung masuk ke halaman ujian dan waktu untuk ujian pun segera berjalan. Di setiap halaman di bagian bawah terdapat tombol "weiter", yang berarti jika diklik, maka hasil pekerjaan mahasiswa di halaman tersebut akan tersimpan secara sementara, dan halaman pun pindah ke halaman selanjutnya.

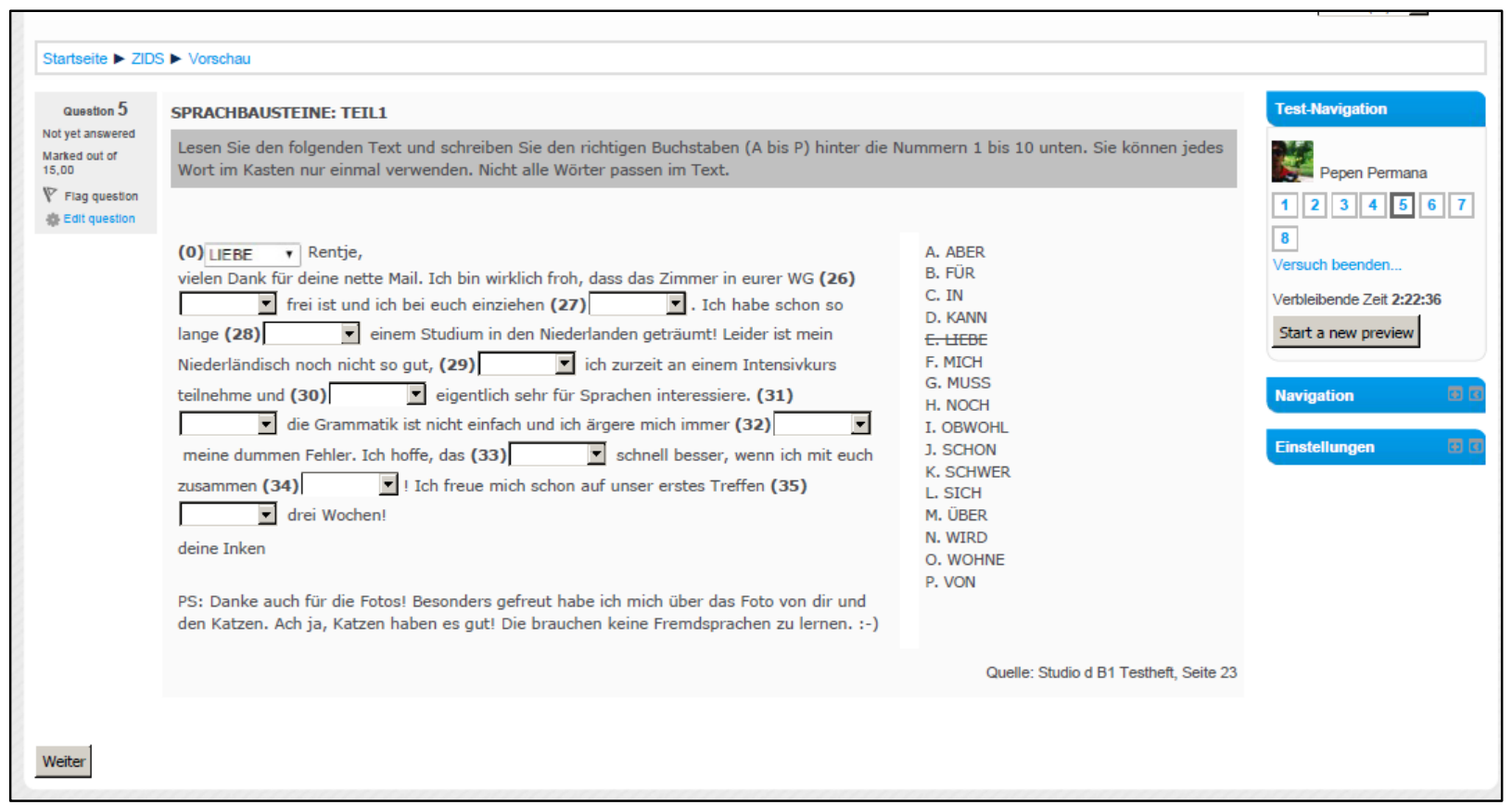

Gambar 2. Contoh Salah Satu Halaman Ujian 
Pada halaman akhir mahasiswa bisa mengetahui ringkasan pekerjaan mereka. Di sini mereka bisa mengecek bagian ujian mana saja yang telah dijawab dan mana yang belum. Mahasiswa dapat kembali mengerjakan soal yang belum dijawab selama waktu masih tersedia dengan mengklik tombol "return to attempt", atau menyudahi simulasi ujian ini dengan mengklik tombol "abgabe". Segera setelah tombol "abgabe" tersebut diklik, maka semua jawaban mahasiswa akan tersimpan di server, dan sistem akan menunjukkan hasil simulasi mahasiswa yang bersangkutan.

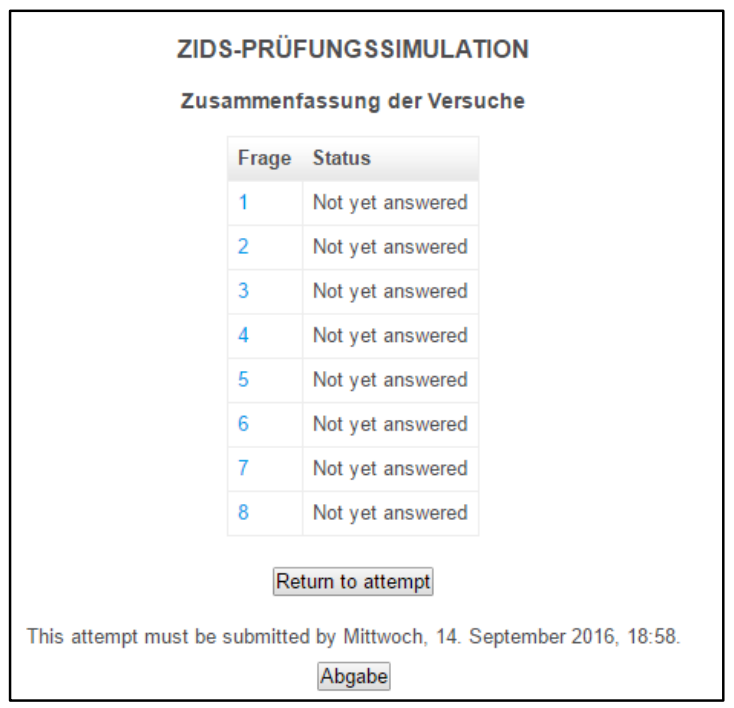

Gambar 3. Contoh Ringkasan Simulasi pada Halaman Akhir

Selama waktu simulasi masih tersedia, mahasiswa dapat bernavigasi dari satu halaman ke halaman lainnya. Hal ini bertujuan agar dapat membantu mahasiswa untuk mengecek jawaban mereka pada tiap halaman. Jika waktu habis, sistem secara otomatis akan menutup program simulasi ini dan semua pekerjaan mahasiswa yang masih terbuka akan langsung tersimpan di dalam server. Dan sistem pun segera menampilkan halaman akhir yang berisi rekapitulasi pekerjaan mahasiswa. Gambar 2 berikut menunjukkan ilustrasi alur navigasi dari program simulasi ujian ZIDS online.

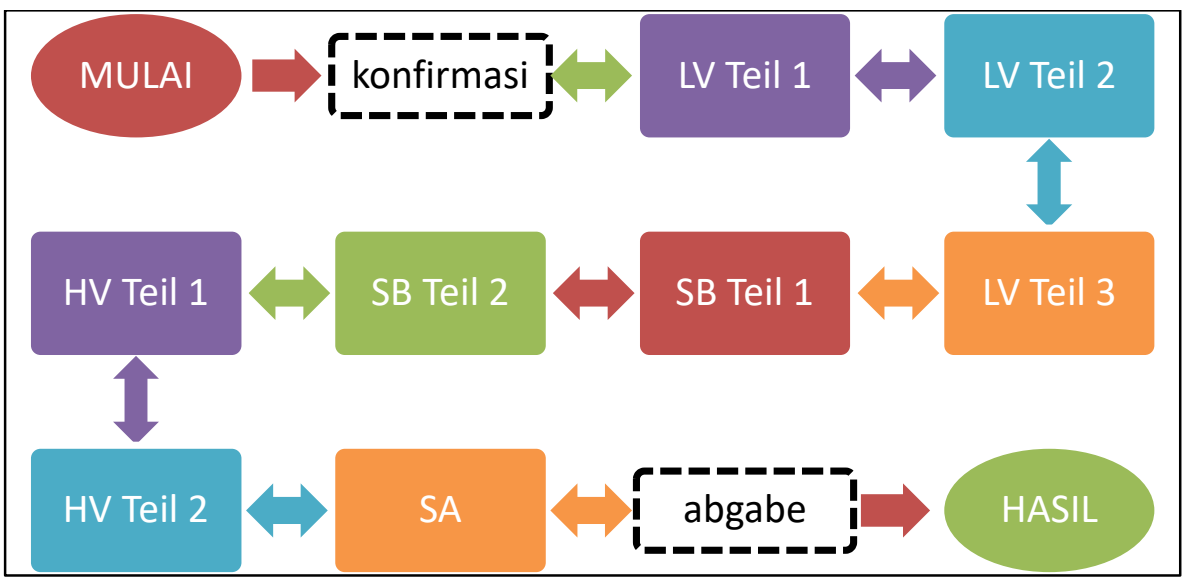

Gambar 4. Flow Chart Navigasi Simulasi Ujian ZIDS Online

Program simulasi ujian ZIDS online

ini didesain agar para pengguna mendapatkan paket soal secara acak. Setiap mata uji yang disimulasikan terdiri dari 
beberapa paket soal yang berbeda namun dengan tingkat kesulitan yang relatif sama. Tiap paket tersebut memiliki variasi paket pertanyaan yang beragam. Sehingga kemungkinan mahasiswa untuk dapat mendapat paket soal yang sama persis dapat diminimalisir. Begitu pula jika mahasiswa melakukan percobaan simulasi untuk kedua kali atau ke sekian kalinya, mereka mendapatkan soal yang berbeda dari soal sebelumnya. Namun demikian, karena saat ini baru tersedia tiga paket soal, tidak tertutup kemungkinan mahasiswa mendapat soal yang berulang, karena bisa saja tiga paket soal tersebut tidak mencukupi untuk dilakukan randomisasi pertanyaan. Untuk itu, ke depannya akan ditambah lagi beberapa paket pertanyaan, agar kemungkinan munculnya soal acak lebih besar.

\section{SIMPULAN}

Program simulasi ujian ZIDS online ini dikonfigurasi dan dikembangkan sedemikian rupa, agar menyerupai bentuk ujian ZIDS yang sebenarnya. Hal ini dilakukan agar para mahasiswa dapat mengenali format ujian ZIDS dan dapat membiasakan diri dengan format tersebut. Sistem penilaiannya pun disusun mendekati hasil ujian ZIDS sesungguhnya, agar mahasiswa dapat mengukur kemampuan mereka dalam ujian ZIDS secara realistis. Masukan jawaban yang diberikan oleh mahasiswa dinilai secara otomatis. Kecuali mata uji SA, yang sifatnya uraian, harus dinilai manual oleh dosen.

Program simulasi ujian ZIDS online ini merupakan produk yang akan terus mengalami perkembangan. Pada saat ini (September hingga Oktober 2016) sedang dilakukan ujicoba terbatas pada mahasiswa bahasa Jerman UPI, dan akan dilanjutkan dengan penyebaran angket untuk mengetahui respon mahasiswa tentang keterpakaian program simulasi ini. Hasil ujicoba dan penyebaran angket tersebut berguna untuk menguji efektivitas dan kebermanfaatan program ini dan untuk melakukan tindakan perbaikan produk dan pengembangan lebih lanjut agar program simulasi ini di masa yang akan datang dapat pula dimanfaatkan oleh mahasiswa bahasa Jerman di seluruh Indonesia.
Berdasarkan hal di atas maka untuk saat ini disarankan kepada para mahasiswa Departemen Pendidikan Bahasa Jerman FPBS UPI untuk dapat memanfaatkan program ini sebaik mungkin dan memberikan masukan membangun demi kesempurnaan program simulasi ujian ZIDS online ini.

\section{DAFTAR PUSTAKA}

Aktivitäten. (2012). [online]. Verfügbar: https://docs.moodle.org/29/de/Ak tivitäten. [10 Februari 2015]

Álvarez, I.A., \& González, L.P., (2007). Blended-learning in ESP:An insight in Moodle. Linguax. Revista de Lenguas Aplicadas, Volume Desember 2007. 4 - 14 .

Ellis, R. (2009). A Field Guide to Learning Management Systems. Learning Circuit.

Miyazoe, T. (2008). LMS-based EFL blended learning: Blackboard vs. Moodle. In K. Bradford Watts, T. Muller, \& M. Swanson (Eds.), JALT2007 Conference Proceedings. Tokyo: JALT

Moodlein der Bildung. (2012). [online]. Verfügbar: https://docs.moodle.org/29/de/M oodle_in_der_Bildung. [25 Juni 2016]

Nozawa, K., (2011). To Moodle or Not To Moodle: Can It Be an Ideal eLearning Environment?, Ritsumeikan University Journal of Policy Science, Bulletin of Universities and Institutes, 289312.

Philosophie. (2012). [online]. Verfügbar: https://docs.moodle.org/31/de/Ph ilosophie. [18 Agustus 2016]

Sahin-Kizil, A. (2014). Blended instruction for EFL learners: Engagement, learning and course satisfaction. Jalt Call Journal Vol. 10 No. 3. 175 188 
Barista: Jurnal Kajian Bahasa dan Pariwisata

p-ISSN 2356-1602 I e-ISSN 2622-5999

\section{UCAPAN TERIMA KASIH}

Terima kasih yang sebesar-besarnya kami ucapkan kepada semua pihak yang telah berkontribusi dalam pelaksanaan penelitian ini: staf LPPM UPI, staf Direktorat TIK UPI, staf Departemen Pendidikan Bahasa Jerman FPBS UPI, dan para mahasiwa yang terlibat sebagai subjek penelitian. Ucapan terima kasih kami ucapkan juga pada para panitia Forum Ilmiah FPBS XII yang telah menerima artikel ini untuk disampaikan pada kegiatan tersebut. 